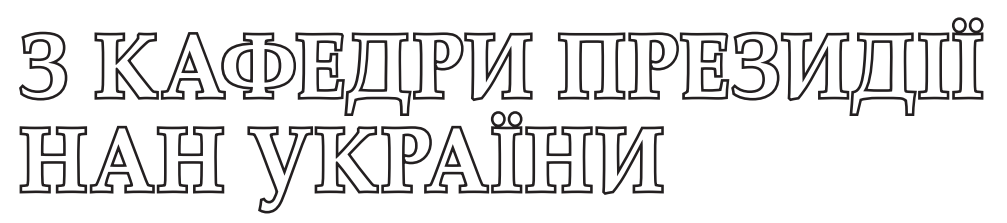

doi: https://doi.org/10.15407/visn2021.10.024

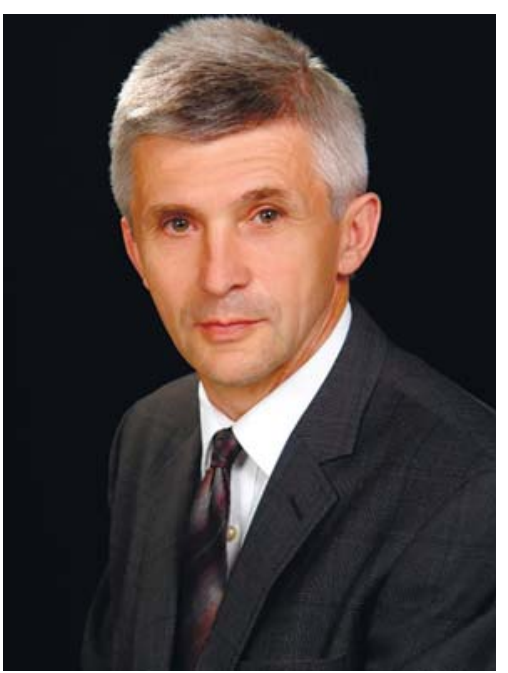

АЖНЮК

Богдан Миколайович член-кореспондент НАН України, директор Інституту мовознавства ім. О.О. Потебні НАН України

\section{ПРО ДІЯЛЬНІСТЬ МОВОЗНАВЧИХ УСТАНОВ НАН УКРАЇНИ В ГАЛУЗІ ЛІНГВІСТИЧНИХ ЕКСПЕРТИЗ}

\author{
Стенограма доповіді на засіданні Президіі \\ НАН України 15 вересня 2021 року
}

У доповіді наголошено на важливості й актуальності нового наукового напряму - лінгвістичної експертології, яка виникла на суміжжі мовознавства та юриспрудениї, і показано, що цей напрям активно розвивається в мовознавчих установах НАН Украйни. Наведено найвагоміші результати теоретичних та прикладних досліджень, окреслено напрями подальшої роботи. Зазначено, що установи НАН Украӥни протягом усвого часу свого існування були і залишаються виконавцями різних типів лінгвістичних експертиз і мають великий досвід їх проведення.

Шановні колеги!

Моя сьогоднішня доповідь стосується участі мовознавчих установ НАН України у проведенні лінгвістичних експертиз усного і писемного мовлення. Це питання дуже широке, тому в часових рамках, відведених для виступу, я спробую окреслити лише його основні аспекти і головну увагу приділятиму методиці проведення таких експертиз.

Лінгвістична експертологія - це досить новий напрям у прикладній лінгвістиці, який виник і розвивається на перетині лінгвістики і права. Існування правових норм було б неможливим без їх письмової фіксації. Мова - це той матеріал, який наповнює право реальним змістом. «Німе» право ніякі відносини регулювати не може.

У стосунках мови і права найбільше значення мають дві обставини. По-перше, правові норми викладено словами живої мови, а одиниці мови не завжди однозначні, вони часто залежать від контексту, соціального сприйняття, граматичних і контекстуальних зв’язків тощо. По-друге, в цьому аспекті мовлення - це не просто передача інформації від джерела до реципієнта. Слово, сказане за певних обставин, стає дією, яка має юридичні наслідки, наприклад при оголошенні пари подружжям, складанні присяги, визнанні або невизнанні вини, оголошенні вироку і т. ін. 
Конфліктні ситуації зазвичай «одягнені» в мовний матеріал. У ході слідства й судового розгляду часто постають питання, що потребують спеціальних лінгвістичних знань. Яке значення має певний елемент висловлення? Однозначний він чи неоднозначний? Чи еквівалентний переклад оригіналові? Чи є в тексті погроза? Чи є в тексті заклик до протиправних дій? Від здатності аргументовано розкрити значення того чи іншого висловлення може залежати, на чию сторону схиляться терези правосуддя.

Мовознавчі установи нашої Академії впродовж усього часу свого існування були і залишаються виконавцями різних експертиз лінгвістичного характеру. Зокрема, коли доповідь на цю тему заслуховували на засіданні Відділення літератури, мови та мистецтвознавства НАН України, про це говорили і директор Інституту української мови НАН України Павло Юхимович Гриценко, і директор Українського мовноінформаційного фонду НАН України академік НАН України Володимир Анатолійович Широков. Експертизи виконуються також на численних мовознавчих кафедрах університетів, наприклад на кафедрі стилістики та мовної комунікації Інституту філології Київського національного університету імені Тараса Шевченка, яку очолює член-кореспондент НАН України Лариса Іванівна Шевченко. Крім того, в Науковій раді НАН України «Інформація, мова, інтелект» (голова - академік НАН України Олександр Васильович Палагін) також розробляється відповідна проблематика із застосуванням мовно-інформаційних цифрових технологій.

Однак значна частина лінгвістичних експертиз, які проводять інститути НАН України, належать до жанру науково-технічної експертизи. Зокрема, це експертизи законопроєктів для Верховної Ради України, експертизи нормативних документів для міністерств і відомств тощо. Звісно, ці експертизи дуже важливі, але, як правило, вони не виступають у ролі доказу в суді, а проливають світло на різні важливі обставини мовознавчого характеру, наприклад на функціонування тих чи інших термінів. E також досить великий масив експертиз, які виконують за допомогою цифрових методів.
На них спеціалізується Український мовно-інформаційний фонд НАН України.

Отже, спектр лінгвістичних експертиз дуже широкий, але в цій доповіді йтиметься насамперед про такий специфічний жанр, як судова лінгвістична експертиза, яка виконується за ухвалою суду, слідчого або на звернення адвоката.

Судова лінгвістична експертиза - це спеціалізоване наукове дослідження, регламентоване особливими жанровими й процесуальними вимогами, що полягає в застосуванні спеціальних лінгвістичних знань для з'ясування питань, які можуть мати юридичні наслідки.

Як це відбувається? До Інституту мовознавства ім. О.О. Потебні НАН України або до Державного підприємства «Українське бюро лінгвістичних експертиз НАН України» звертаються, скажімо, слідчі НАБУ з матеріалами прослуховування розмов потенційного корупціонера, вину якого потрібно довести, і ставлять питання, які вони хочуть винести на розгляд експертів. Спочатку відбувається уточнення цих питань, з'ясовується, чи належить їх вирішення до компетенції експертівлінгвістів, і лише після цього подається запит на проведення лінгвістичної експертизи, підписується документ про нерозголошення наданих відомостей, сторони укладають договір і виставляється рахунок на оплату експертних послуг. При цьому процесуально передбачена участь експерта у судовому засіданні, щоб дати відповіді на запитання сторін.

Саме в ділянці судових експертиз найбільшу емпіричну базу і найбільший досвід мають Інститут мовознавства ім. О.О. Потебні та створене постановою Президії НАН України у 2004 р. Українське бюро лінгвістичних експертиз. Характерною ознакою діяльності цих установ є те, що вони виконують судові експертизи не лише українських текстів, а й перекладів або текстових матеріалів, написаних іноземними мовами, що значно ускладнює процес проведення експертизи і підвищує вимоги до методики їі проведення.

Замовниками лінгвістичних експертиз, які використовувалися в судах як докази, були 
суди різних рівнів, Міністерство юстиції України, Служба безпеки України, Національне антикорупційне бюро України, Державне бюро розслідувань України, Міністерство внутрішніх справ України, Генеральна прокуратура та багато інших організацій та відомств.

Фігурантами справ, у яких ми здійснювали судові лінгвістичні експертизи, були відомі банки й корпорації, а серед фізичних осіб відомі політики, імена яких регулярно згадуються українськими й зарубіжними засобами масової інформації. Я згадав про це не задля піару, а тому, що зазвичай адвокати таких потужних фігурантів чіпляються за кожне слово, кожну кому в тексті, докладають неабияких зусиль, щоб спростувати висновки експертів та поламати доказову логіку експертизи. Очевидно, що чим вагоміший фігурант, тим «зубастіші» його адвокати та їхні консультанти i, відповідно, тим вищими є вимоги до якості експертного висновку.

Маючи в своєму розпорядженні величезну базу емпіричних матеріалів і багаторічний досвід проведення судових лінгвістичних експертиз, ми вважаємо за доцільне узагальнити свої напрацювання у вигляді методики. Річ у тому, що досить часто експертні установи різних відомств відмовляються від виконання експертизи, посилаючись на відсутність відповідних методик. Ті методики, які нині є в реєстрі Міністерства юстиції, доволі застарілі і не охоплюють усього спектру сучасних лінгвістичних експертиз. Так, з 16 типів найпоширеніших експертиз 9 не мають відповідних методик, про них навіть ніде не згадується і складається враження, що їх просто не існує. Зокрема, жодна з методик не описує такі види експертиз:

- експертизи мовленнєвих дій, спрямованих на зміни меж території та державного кордону України;

- експертизи щодо посягання на мовні права носіїв державної мови та носіїв мов України;

- експертизи 3 виявлення ознак погрози, шантажу, вимагання або пропонування неправомірної винагороди та згоди на її отримання;

- експертизи, пов’язані з введенням в оману (тексти реклами, написів на етикетках товарів, інструкцій про застосування лікарського засобу тощо);

- експертизи перекладу;

• експертизи документальних записів власних назв;

- експертизи, пов'язані з мовленнєвими діями, які містять невербальні складники (жести, піктограми тощо).

Чому ми наважилися взятися за розроблення методик судових лінгвістичних експертиз? Тому що, як я вже казав, ми маємо, мабуть, найбільшу в Україні базу відповідних емпіричних матеріалів. Ми маємо великий досвід участі в судових засіданнях і відповідей на запитання сторін, адже діалог юриста і лінгвіста має свої характерні особливості. У нас висока апробованість результатів, тобто велика кількість судових рішень, ухвалених з використанням наших експертиз. Ми налагодили тісну взаємодію з провідними українськими юристами, Національною асоціацією адвокатів України, експертними установами Мін'юсту та інших міністерств і відомств. Наші співробітники мають глибокі теоретичні напрацювання і значну кількість наукових публікацій, зокрема монографій, а також досвід проведення наукових конференцій, семінарів з підвищення кваліфікації нотаріусів, правників та інших фахівців.

Окремо хочу наголосити на важливості теоретичних засад судової лінгвістичної експертизи. $\mathrm{C}$ відомий народний вислів: «Закон як дишло - куди повернеш, туди й вийшло», і щоб він не реалізувався на практиці в тлумаченні закону, в основу лінгвістичної експертизи покладено концепцію лінгвальної визначеності тексту як передумови його юридичної визначеності.

Лінгвальна визначеність мовного об'єкта забезпечує принципову можливість його недвозначної лінгвістичної інтерпретації, за необхідності - з опорою на спеціальні знання лінгвістів. Лінгвальна визначеність мовних об’єктів $€$ необхідною передумовою однаковості застосування юридичної норми. Лінгвістична експертиза виходить із презумпції лінгвальної визначеності мовних об'єктів, які належать до інституціоналізованих дискурсів, доки не доведено протилежне.

ISSN 1027-3239. Visn. Nac. Acad. Nauk Ukr. 2021. (10) 
Лінгвальна визначеність характеризує інституціоналізований дискурс у цілому й передбачає, що навіть якщо окремий фрагмент текстового матеріалу не забезпечує комунікативної точності та однозначності, то ширший контекст, а також інші дискурсивно пов’язані тексти передбачають можливість досягнення такої однозначності.

Коли протистоять дві інтерпретації тексту, важливо показати не тільки обгрунтованість однієї з них, а й безпідставність іншої. Тоді експертиза є переконливою і має запас міцності.

Належність тексту до певного дискурсу суттєво впливає на комунікативні очікування адресата повідомлення. Якщо ми порівняємо друкований медійний текст, текст усного публічного виступу і запис прослуховування трьох підозрюваних у кафе, то зрозуміємо, що комунікативна специфіка важлива. Тому для експертизи тексту вихідною є презумпція осмисленого й адекватного сприйняття цього тексту його адресатом з урахуванням дискурсивної специфіки. Вона допомагає «відсікати» аномальні інтерпретації й викривлені смисли, породжувані психологічною своєрідністю або нестандартністю критеріїв інтерпретатора. Без такої презумпції аргументована лінгвістична оцінка тексту неможлива.

У справах про погрози завданням лінгвістичної експертизи є виявити саму наявність погрози і встановити, в чому полягає їі зміст. У багатьох випадках, щоб правильно діагностувати комунікативний статус висловлення, тобто провести грань між епатажними висловленнями, порушеннями мовного етикету (такими як хамство, прокльони і т. ін.), з одного боку, і погрозою, з другого боку, потрібні спеціальні лінгвістичні знання.

Практика лінгвістичних експертиз і пов'язані з нею теоретичні дослідження показують, що встановлення факту погрози має спиратися не на суб'єктивне сприйняття певного висловлення його адресатом, а насамперед на об’єктивну реальність тексту. Наприклад, у нашій практиці був такий випадок. Учасник судового засідання, молодий адвокат, дозволив собі неввічливі висловлення на адресу судді.
Останній, бажаючи покарати грубіяна, подав на нього позов зі звинуваченням у погрозах. Протокол та аудіозапис судового засідання стали об'єктом лінгвістичного дослідження, яке встановило, що висловлення відповідача не містять погроз, хоча й можуть бути підставою для покарання за неповагу до суду.

Специфіка експертизи діалогічного тексту (записи розмов та переговорів, обмін CMCповідомленнями тощо) полягає в тому, що значна частина інформації, якою оперують співрозмовники, не набуває прямого словесного вираження і перебуває в підтексті: часто не договорюють того, про що співрозмовник знає або здогадується, осіб або об'єкти називають не по імені, а вживають займенникові позначення тощо. Це ускладнює розуміння тексту невтаємниченим слухачем і його використання як доказу в судовому засіданні.

Завданнями цього типу експертиз є виявити висловлення, які спонукають адресата до вчинення певних дій (наприклад, у справах про шахрайство), ідентифікувати особу, яка називається в тексті непрямим способом або описово, виявити приховані засоби мовленнєвого впливу на особу, встановити, в чому полягає такий вплив, і т. ін. Специфічним об'єктом дослідження є значення жестів, що супроводжують або замінюють словесні засоби вираження в потоці спонтанного мовлення.

Завданням лінгвістичної експертизи у справах про розпалювання міжнаціональної ворожнечі є зазвичай виявлення слів і висловів, що вказують на негативне ставлення до представників певної етнічної (расової, релігійної) групи, інформації про вищість однієї етнічної (расової, релігійної) групи над іншими, закликів до насильства щодо представників певної етнічної (расової, релігійної) групи тощо.

Нерідко об'єктом дослідження стає значення фахових термінів, зокрема тих, що зазнають модифікацій під впливом контексту або з інших причин, перекладних термінів, термінівнеологізмів та ін. Спірні інтерпретації текстів виникають також через різнотлумачення таких юридизованих мовних одиниць, як складений сполучник та/або, слово тощо, вислів $i m$. $i$., 
абревіатура $y$. о., вживання розділових знаків, складних синтаксичних конструкцій тощо.

Важливою ділянкою практичної діяльності експертів є аналіз тексту перекладу порівняно з оригінальним текстом. Нам доводилося виконувати експертизи спірних договорів, які розглядалися в міжнародних арбітражних судах, зокрема щодо значення англійських термінів та їх відповідників українською й російською мовами. Спектр значень терміна, наведений у загальномовному перекладному словнику чи навіть у спеціалізованому юридичному словнику, далеко не завжди вичерпний. У певному контексті фаховий термін може набувати змістових уточнень та додаткових значеннєвих відтінків. Визначити точність його відображення в перекладі можна з допомогою фахового лінгвістичного дослідження. Наприклад, широко відомий англійський термін joint venture найчастіше перекладається як спільне підприємство. Однак у деяких контекстуальних обставинах, коли термін позначає бізнесову діяльність, яка не передбачає створення суб'єктами цієї діяльності єдиної юридичної особи, його найбільш точним відповідником є українське словосполучення спільна діяльність. Ми довели, що в досліджуваному контексті єдино можливим українським відповідником вислову joint venture є спільна діяльність, оскільки загальний зміст фрази та лексична валентність англійського компонента have embarked унеможливлює використання в перекладі українського вислову спільне підприємство.

Ще один характерний приклад. В англійському тексті контракту вживається вислів arbitration panel. Для розв'язання спору на розгляд експерта-лінгвіста було винесено низку питань: 1) Яке значення має англійське слово panel у складі юридичного терміна arbitration panel? 2) Чи є англійські терміни arbitration panel та arbitration tribunal тотожними за змістом? Чи можуть ці терміни вживатися як взаємозамінні в офіційно-діловому тексті або в перекладі офіційно-ділового тексту? 3) Чи завжди слово panel у складі юридичного терміна arbitration panel вказує на колегіальний орган? Якщо ні, то в яких випадках воно вказує на орган, який не є колегіальним, а складається з однієї особи? Експертиза встановила, що вислови arbitration panel та arbitration tribunal не можуть вживатися як взаємозамінні в офіційно-діловому тексті, а слово panel у складі юридичного терміна arbitration panel вказує на колегіальний орган.

Часто об'єктами експертизи є власні назви. Насамперед це документальні записи прізвищ, імен, по батькові, між якими виникли розбіжності внаслідок перекладу або уживання архаїчних, діалектних, гіпокористичних, просторічних форм і т. ін. Наприклад, на Закарпатті ім'я Ернст під фонетичним впливом угорської мови (Ernő) набуває форми Ерньов (варіант Ернев). У цьому ж регіоні поширені варіанти прізвищ на зразок Сабо - Сабов, Санісло Саніслов і т. ін. $€$ варіанти імен, які в певному мовному ареалі використовуються як взаємозамінні, хоча мають значні орфографічні відмінності, наприклад, Адальберт - Ольбрахт Бейла (варіанти Бела, Бейло, Бийла, Бийло), Василь - Ласло - Ладіслав та деякі інші.

У тюркських мовах записи по батькові мають аналітичну форму, відмінну для осіб чоловічої й жіночої статі. Наприклад, за азербайджанською національною традицією утворення форм по батькові відбувається шляхом додавання до імені батька елементів oğlu (в українській мові має фонетичні варіанти огли/ оглу) для осіб чоловічої статі або qіzі (українські фонетичні варіанти кизи/гизи) для осіб жіночої статі. У час перебування Азербайджану в складі СРСР документальні записи імені по батькові часто робили за зразком російської мови, шляхом додавання у фіналі -ович, (-евич), -овна (-евна) до основи особового імені. Аналогічні форми імені по батькові -ович, -йович, -івна, -їва застосовувалися в документальних записах українською мовою. Ідентичність документальних записів на зразок Алярович - Аляр огли, Арсенович - Арсен угли, Тазалї̈вна - Тазалі кзи і т. ін. можна підтвердити шляхом лінгвістичної експертизи.

Мають свою специфіку і записи литовських прізвищ. Наприклад, якщо в чоловіка прізвище Рагаускас, то в його дружини - Рагаускене,

ISSN 1027-3239. Visn. Nac. Acad. Nauk Ukr. 2021. (10) 
а в дочки - Рагаускюте. Лінгвістична експертиза допомагає встановити спорідненість носіїв відмінних форм прізвищ такого типу.

Важливим аспектом роботи лінгвістів-експертів є виконання державної мовної експертизи, передбаченої прийнятим у 2019 р. Законом України «Про забезпечення функціонування української мови як державної». За цим законом підставою для проведення експертизи є прийняття Уповноваженим із захисту державної мови рішення щодо заяви або скарги, яка перебуває на розгляді. Закон передбачає, що Положення про державну мовну експертизу затверджує Кабінет Міністрів України. У рамках Меморандуму про співпрацю між Уповноваженим із захисту державної мови та Національною академією наук України Інститут мовознавства ім. О.О. Потебні НАН України підготував проєкт відповідного Положення і передав його в офіс Уповноваженого із захисту державної мови.

На нашу думку, для підвищення ефективності лінгвістичних експертиз потрібно було б вжити низку заходів, зокрема:

- організувати проведення спеціальних семінарів для підвищення кваліфікації експертів;

- забезпечити публікацію й поширення методичних посібників для потреб експертної діяльності;

- налагодити підготовку експертів через аспірантуру Інституту мовознавства ім. О.О. Потебні НАН України;

- посилити обмін досвідом із зарубіжними фаховими осередками через проведення спільних наукових конференцій.
Крім того, дуже важливо поширювати у фаховому середовищі правників знання про можливості лінгвістичних експертиз та їх основні засади. Видається доцільним проведення на кадровій і науково-методичній базі мовознавчих установ НАН України спеціальних семінарів 3 практики застосування лінгвістичних експертиз для систем підвищення кваліфікації суддів, прокурорів, слідчих, адвокатів, державних службовців, працівників апарату органів влади тощо.

Ми вже маємо досвід проведення подібних семінарів на курсах підвищення кваліфікації нотаріусів, а також у Київському науково-дослідному інституті судових експертиз - провідній установі Міністерства юстиції України, з якою підтримуємо тісні професійні контакти. Готові організувати масштабну наукову конференцію із залученням українських і зарубіжних експертних установ.

Звичайно, ця доповідь не може охопити всіх аспектів лінгвістичної експертної діяльності. Однак я намагався показати, наскільки ця тема сьогодні є актуальною. Для проведення сучасної фахової лінгвістичної експертизи потрібні різні інструменти, в тому числі й мовно-інформаційні та цифрові технології. Але насамперед необхідні чітко окреслені методологічні засади. Саме тому ми пропонуємо розроблену нами методику, яку ми готові й далі доповнювати, уточнювати, вдосконалювати, але вона, поза сумнівом, більшою мірою відповідає вимогам сьогодення, ніж ті методики, які є на цей час.

Дякую за увагу!

За матеріалами засідання підготувала О.О. Мележик

Bohdan M. Azhniuk

ORCID: https://orcid.org/0000-0002-9496-1544

Potebnia Institute of Linguistics of the National Academy of Sciences of Ukraine, Kyiv, Ukraine

ON THE ACTIVITY OF LINGUISTIC INSTITUTIONS OF THE NAS OF UKRAINE IN THE FIELD OF LINGUISTIC EXAMINATIONS

Transcript of scientific report at the meeting of the Presidium of NAS of Ukraine, September 15, 2021

The report emphasizes the importance and relevance of a new scientific field, linguistic examination, which emerged on the border of linguistics and jurisprudence, and shows that this area is actively developing in the linguistic institutions of the NAS of Ukraine. The most important results of theoretical and applied researches are given, the directions of further work are outlined. It is noted that the institutions of the NAS of Ukraine throughout their existence have been and remain performers of various types of linguistic examinations and have extensive experience in conducting them. 